\title{
BOOK REVIEW: Flora of Cambodia, Laos and Vietnam
}

Fascicle 33 Apocynaceae by David J. Middleton. 2014.

(288 pages, 48 colour photographs, 48 line drawings; paperback; text in English; $160 \times 240$ $\mathrm{mm}$. ISBN 978-2-85653-751-0. £35 incl. packing \& postage)

Fascicle 34 Polygalaceae by Colin A. Pendry. 2014.

(72 pages, 14 colour photographs, 5 line drawings; paperback; text in English; $160 \times 240 \mathrm{~mm}$. ISBN 978-2-85653-752-7. £15 incl. packing \& postage)

Fascicle 35 Solanaceae by Sovanmoly Hul \& Pauline Dy Phon. 2014.

(104 pages, 29 colour photographs, 25 line drawings; paperback; text in French; $160 \times 240 \mathrm{~mm}$. ISBN 978-2-85653-750-3. £20 incl. packing \& postage)

Paris: Publications scientifiques du Muséum national d'Histoire naturelle \& Edinburgh: Royal Botanic Garden Edinburgh.
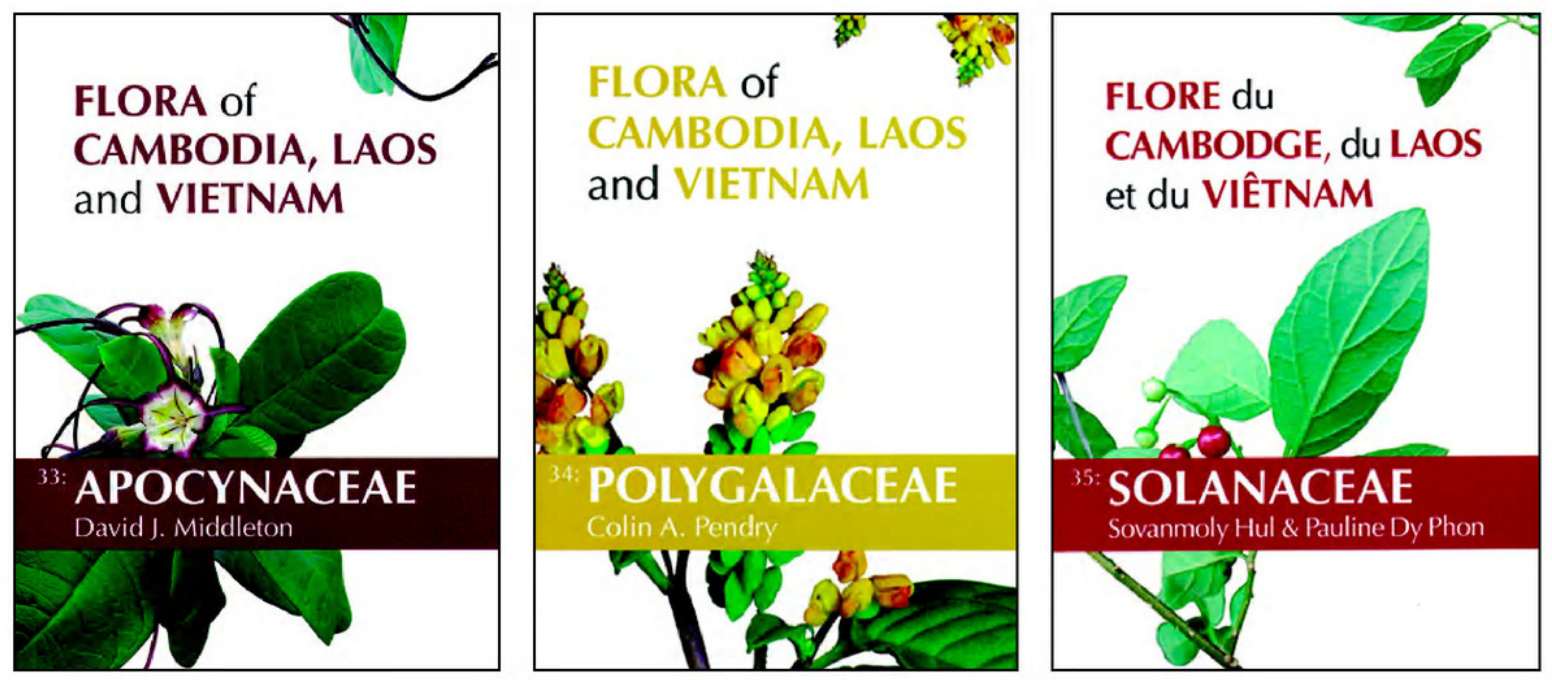

It has been ten years, a whole decade, after the publication of the last issue of the Flore du Cambodge, du Laos et du Viêtnam (Flora of Cambodia, Laos and Vietnam, or FCLV), a project begun by André Aubréville in 1960 to succeed La Flore générale de l'Indochine (The General Flora of Indochina) coordinated by H. Lecomte \& H. Humbert during 1907-1934, and H. Humbert until 1951. That last issue was Fascicle 32, Myrsinaceae, by Chi Ming Hu \& Jules Vidal, issued in December 2004.

The new issues are Fascicle 33 (Apocynaceae, by David J. Middleton, in English), Fascicle 34 (Polygalaceae, by Colin A. Pendry, in English), and Fascicle 35 (Solanaceae, by Sovanmoly Hul \& Pauline Dy Phon, in French), all issued in December 2014.

These finely produced issues not only welcome back a key regional project after a hiatus but also see a redoubled organisation and collaboration to engage more specialists in what is the longest-running international science endeavour in the Cambodia, Laos and Vietnam (CLV) region. The added use of English as an alternative language will certainly make the revisions more amenable to potential contributors as well as more accessible to users of floras.

It is easy to see why botanists have been attracted to this region and perhaps also fairly easy to understand why efforts at the documentation of the plant life have 
not been on a dauntless path since the Portuguese Jesuit missionary João de Loureiro published the Flora Cochinchinensis in 1790. Loureiro's work was an extension of his interest in local medicinal plants after spending 35 years, mostly as chief mathematician and naturalist, in the service of the King of Cochinchina, a region in the southern third of modern Vietnam that included Saigon and Hue, and at some later point a French colony (Merrill, 1935). Loureiro's specimen collections, which would have been important reference material, were partly destroyed, and his plant descriptions were very brief and, understandably, often ambiguous or unclear. The CLV region has been, and is still to a large degree, a landscape difficult to traverse: initially because of thick vegetation cover, disease and mountainous terrain in many parts, and latterly still with the risk posed by landmines from the 20th century war years that riddle parts of the landscape. The relative isolation of mainland SE Asia caused by the Miocene uplift of the Himalayas, connectivity with the Chinese Henduan Mountains to the northwest and the main South Chinese karst region to the north, general climatic distinction from the wetter tropical region of Malesia to the south, as well as emergence through episodes of climatic oscillations, geological changes and vegetation range expansions and contractions, have been important biogeographic features that have shaped a very rich and special biota. Loureiro's work was important but can be difficult to relate to other pioneering botanical work with floristic overlaps in the region, especially when specimen material is lacking or poorly referenced. The trauma of the Second World War and subsequent political realignments and regional conflicts would stretch the pause in scientific research into the 1990s. And, meanwhile, floristic and other progress has raced on around the CLV region. It is not surprising that the CLV flora remains one of the poorest explored and documented, complex to tackle even for the specialist, and for which much painstaking research is now required.

Economic reforms and the opening up of the CLV region have brought its countries into wider collaboration with outside botanical institutions. The early French effort, fostered much through the collecting activities of such as Balansa, Chevalier, Eberhardt, Harmand, Pételot, Pierre, Schmid, Thorel, Vidal, and Poilane, brought in some 75,000 specimen collections (Regalado et al., 2005); probably now over 30,000 collections have been added through collaborative programmes since the 1990s. Encumbered by so many historical factors, it is still most meaningful to approach the flora of this block of mainland SE Asia with a single definitive regional flora - even if each country uses a different language and, as faster progress on the Vietnamese front demonstrates, there is a local need to produce national floras, such as the Flora of Vietnam series (in Vietnamese) initiated through the Hanoi-based Institute of Ecology \& Biological Resources (which can emphasize conservation efforts more directly), and checklists, as in the 3-volume Checklist of Plant Species of Vietnam (in Vietnamese) produced through the Vietnam National University in Hanoi. In the end, all checklists and floras will be subject to revision - some more intensively than others - as further exploration, collecting and revision will show. In this regard, even a number of earlier FCLV accounts are ripe for revision, although tackling these should subsequently be more systematic and easier given its regional scope. Even with a shift towards online floras that are more easily updated as parts are made available, 
continuing the printed version of the FCLV is not without merit. It is one thing being able to access websites with a good satellite cellphone from just about anywhere, and another to afford sufficient and up-to-date computer equipment and software to carry out sustained flora work that could make reference to the results of the published revisions. Moving the taxonomic inventory into many locations on mainland SE Asia, and encouraging sustained local efforts at continuing documentation (the Flora is not an end-point), is not devoid of challenges.

The present treatment of Apocynaceae for Fasc. 33 (38 genera, 119 native spp.) revises only two subfamilies, Rauvolfioideae and Apocynoideae, and does not cover the other three subfamilies which have been traditionally included in the Asclepiadaceae. No genus is overly represented, with the largest mostly 6-10 spp., but more than half of the species are native climbing species, including some big lianas. Seventeen species are endemic to the region, most of them in Vietnam. Another 12 commonly cultivated species are also identified. In all, this Apocynaceae treatment includes 109 species for Vietnam, 64 species for Laos, and 49 species for Cambodia.

In Fasc. 34, Polygalaceae (5 genera, $43 \mathrm{spp}$.) includes the cosmopolitan Polygala (over 500 spp., 22 spp. in CLV), the largest genus in this family of c. 1000 species. Nine species are endemic to the region, again mostly in Vietnam and especially in Xanthophyllum. There are 34 species known in Vietnam, 28 species in Laos, and 16 species in Cambodia. The life form coverage is interesting; besides herbs, shrubs, trees and lianas, there is also the diminutive myco-heterotrophic Epirixanthes elongata, which is an easily overlooked inhabitant of the forest floor but otherwise a widespread taxon ranging from $\mathrm{E}$ India to $\mathrm{S}$ China and Moluccas.

Fasc. 35 presents the Solanaceae ( 8 genera, 48 spp. including Solanum camranhense Dy Phon \& Hul newly published in the revision) and includes Solanum, the largest genus in the family (c. 1500 spp., 34 spp. in CLV). In CLV all Capsicum, Cestrum, Datura, Lycium, Nicotiana and Physalis species, along with numerous Solanum species, are introduced from the New World: they include weeds as well as major and minor crops. Only five species are apparently endemic to the region. There are 41 species known in Vietnam, 29 species in Laos, and 23 species in Cambodia.

Standard inclusions for all three revisions are a concise introduction with notes on taxonomy, diversity, morphology, palynology, karyology and pertinent biological aspects as known, uses, keys (to genera, and also to species) and detailed descriptions of all taxa, with notes on ecology and distribution. Citations of specimens studied are provided. The descriptions in Polygalaceae and Solanaceae are of about maximum length compared to past revisions in the FCLV, but the Apocynaceae treatment includes some lengthy descriptions in a number of cases. For Solanaceae, good notes are given on the local use of numerous species and at the end of the volume there is an index of vernacular names in different native languages. There are a good number of rather exquisite line illustrations in the Apocynaceae ( 48 by Alain Jouy) and Solanaceae ( 25 by Dominique Storez and Alain Jouy) issues, but far fewer for Polygalaceae (only five by Holly Somerville); the inclusion of colour images of species as plates in the final section of each issue is helpful ( 8 plates for $38 \mathrm{spp}$. in Apocynaceae, 4 for $8 \mathrm{spp}$. in Polygalaceae, 7 for $16 \mathrm{spp}$. in Solanaceae). The presentation of genera is alphabetical 
for Apocynaceae but not so for the other two revisions. Printing quality is excellent but the text font style tends to deliver a somewhat faint print.

Overall, these have been excellently produced. The FCLV is well off on its second leg.

\section{References}

Merrill, E.D. (1935). A commentary on Loureiro's 'Flora Cochinchinensis'. Trans. American Philos. Soc., n.s., 24(2): 1-445.

Regalado, Jr., J.C., Nguyen Tien Hiep, Phan Ke Loc, Averyanov, L. \& Harder, D.K. (2005). New insights into the diversity of the Flora of Vietnam. In: Friis, I. \& Balslev, H. (eds) Plant Diversity and Complexity Patterns: Local, Regional, and Global. Proceedings of an international symposium held at the Royal Danish Academy of Sciences and Letters, Copenhagen, Denmark, 25-28 May, 2003. Det Kongelige Danske Videnskabernes Selskab, Denmark.

\section{K.M. Wong \& M. Rodda \\ Singapore Botanic Gardens}




\section{$2 \mathrm{BHL}$ Biodiversity Heritage Library}

Wong, K. M. and Rodda, Michele. 2015. "Book Review: Flora of Cambodia, Laos and Vietnam." The Gardens' bulletin, Singapore 67(2), 411-414. https://doi.org/10.3850/s2382581215000356.

View This Item Online: https://www.biodiversitylibrary.org/item/223140

DOI: https://doi.org/10.3850/s2382581215000356

Permalink: https://www.biodiversitylibrary.org/partpdf/229533

\section{Holding Institution}

Singapore Botanic Gardens, National Parks Board Singapore

\section{Copyright \& Reuse}

Copyright Status: In copyright. Digitized with the permission of the rights holder.

License: http://creativecommons.org/licenses/by-nc-sa/4.0/

Rights: https://biodiversitylibrary.org/permissions

This document was created from content at the Biodiversity Heritage Library, the world's largest open access digital library for biodiversity literature and archives. Visit BHL at https://www.biodiversitylibrary.org. 